\title{
Lizimetre kullanılarak Maraş 18 çeşidi ceviz ağacının su tüketiminin belirlenmesi
}

\section{Determination of water consumption of Maras 18 type walnut tree using lysimeter}

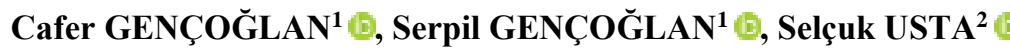

${ }^{1}$ Kahramanmaraş Sütçü İmam Üniversitesi, Ziraat Fakültesi, Biyosistem Mühendisliği Bölümü, 46040, Kahramanmaraş ${ }^{2}$ Van Yüzüncü Y1l Üniversitesi, Van Meslek Yüksekokulu, İnşaat Bölümü, 65090, Van

Sorumlu yazar (Corresponding author): S. Usta, e-posta (e-mail): susta@yyu.edu.tr Yazar(lar) e-posta (Author e-mail): gencoglan@ksu.edu.tr, sgencoglan@ksu.edu.tr

\section{MAKALE BILLGISİ}

Alınıs tarihi 11 Mayıs 2020

Düzeltilme tarihi 28 Mayıs 2020

Kabul tarihi 01 Haziran 2020

\section{Anahtar Kelimeler:}

Ceviz

Lizimetre

Maraș 18

Sulama

Su tüketimi

\begin{abstract}
ÖZ
Son yıllarda ceviz yetiştiriciliğine olan ilginin artmasıyla birlikte kurulan yeni ceviz bahçelerinin sayısı da hızla artmaktadır. Bu bahçelerde yetiştirilecek meyve verimi yüksek ceviz ağaçlarının su tüketimlerinin bilinmesine ihtiyaç duyulmaktadır. Bu çalışmada, yüksek meyve verimine sahip olan Maraş 18 çeşidi ceviz ağacının Kahramanmaraş koşullarındaki su tüketimi miktarının belirlenmesi amaçlanmışıı. Bu amaç doğrultusunda lizimetre, elektronik kantar, tahliye tank1, plüviyometre ve damla sulama sisteminden meydana gelen bir tartıl lizimetre sistemi (TLS) oluşturulmuştur. TLS, Programlanabilir Lojik Kontrolör cihazı (PLC) tarafından kontrol edilmiștir. Öncelikle TLS koşullarında bir boyutlu su dengesi yöntemi uygulanarak, iki yaşındaki genç ceviz ağacının 2018 yılı Haziran - Ekim dönemi boyunca günlük su tüketimi miktarları ( $\mathrm{ET}_{\text {genc }}$ ) belirlenmiștir. Daha sonra $\mathrm{ET}_{\text {genc }}$ miktarlarına bağl olarak, yetişkin ceviz ağaçlarının günlük su tüketimi miktarları $\left(\mathrm{ET}_{\text {yetişkin }}\right)$ tahmin edilmiştir. Genç ceviz ağacı için 1.22 - $3.20 \mathrm{~mm}_{\text {gün }}{ }^{-1}$ arasında değişen $\mathrm{ET}_{\text {genç }}$ miktarları elde edilmiş̧tir. İki yaşındaki genç ceviz ağaçlarının yetişkin ceviz ağaçlarının \%30 - 40'1 oranında su tükettikleri göz önünde bulundurularak, 15 günlük dönemler için $\mathrm{ET}_{\text {yetiskin }}$ miktarları tahmin edilmiştir. $\mathrm{ET}_{\text {yetiskin }}$ miktarları Haziran ayı için $6.77 \mathrm{~mm}_{\text {gün}}{ }^{-1}$, Temmuz ayı için 8.49 - 9.14 $\mathrm{mm}$ gün ${ }^{-1}$, Ağustos ayı için $5.71-6.00 \mathrm{~mm}_{\text {gün }}{ }^{-1}$, Eylül ayı için $3.86-7.43 \mathrm{~mm}$ gün ${ }^{-1}$ ve Ekim ayı için $3.49 \mathrm{~mm}_{\text {gün }}{ }^{-1}$ olarak tahmin edilmiştir. $\mathrm{ET}_{\text {yetiskin }}$ miktarlarının "Türkiye'de Sulanan Bitkilerin Su Tüketim Rehberi” ile \%80 oranında uyumlu oldukları ve yetişkin ceviz ağaçları için hazırlanacak sulama programlarında kullanılabilecekleri sonucuna ulaşılmıştır.
\end{abstract}

\section{ARTICLE INFO}

Received 11 May 2020

Received in revised form 28 May 2020

Accepted 01 June 2020

\section{Keywords:}

Walnut

Lysimeter

Maraş 18

Irrigation

Water consumption

\begin{abstract}
With the increasing interest in walnut cultivation in recent years, the number of new walnut orchards established has been increasing rapidly. It is necessary to know the water consumption of walnut trees with high fruit yield to be grown in these orchards. In this study, it was aimed to determine the water consumption of Maraş 18 type walnut tree, which has a high fruit yield, in Kahramanmaraş conditions. For this purpose, a weighting lysimeter system (WLS) was created consisting of lysimeter, weighbridge, discharge tank, pluviometer and drip irrigation system. WLS was controlled by Programmable Logic Controller (PLC) device. Firstly, daily water consumption of two years old young walnut tree $\left(\mathrm{ET}_{\text {young }}\right)$ were determined by applying one dimensional water balance method under WLS conditions, during the June - October period of 2018. Then, daily water consumptions of mature walnut trees $\left(\mathrm{ET}_{\text {mature }}\right)$ were estimated depending on the amounts of $\mathrm{ET}_{\text {young. }} . \mathrm{ET}_{\text {young }}$ amounts ranging from 1.22 to $3.20 \mathrm{~mm} \mathrm{day}^{-1}$ were obtained for the young walnut tree. By taking into consideration that two years old young walnut trees consume ratio $30-40 \%$ water of adult walnut trees, $\mathrm{ET}_{\text {mature }}$ amounts were estimated for 15 day periods. The amounts of $\mathrm{ET}_{\text {mature }}$ were estimated as $6.77 \mathrm{~mm} \mathrm{day}^{-1}$ for June, 8.49 and $9.14 \mathrm{~mm}^{-12 y^{-1}}$ for July, 5.71 and $6.00 \mathrm{~mm}^{-1 a y^{-1}}$ for August, 3.86 and $7.43 \mathrm{~mm}$ day $^{-1}$ for September and $3.49 \mathrm{~mm}$ day $^{-1}$ for October. It has been concluded that $\mathrm{ET}_{\text {mature }}$ amounts are compatible with "Water Consumption Guide of the irrigated crops in Turkey" at ratio $80 \%$ and can be used in irrigation programs to be prepared for mature walnut trees.
\end{abstract}




\section{Giriş}

Dünyada yaygın olarak yetiştiriciliği yapılan cevizin (Juglans regia L.) gen merkezleri arasında Türkiye'de bulunmaktadır. Ceviz, 2300 m yüksekliğe kadar değişik iklim koşullarında rahatlıkla yetiştirilebilmektedir (Toprak ve Bayrak 1998). Taze veya kuru olarak tüketilebilen ceviz, şekerleme ve şıra ürünlerinin yapımında hammadde olarak da kullanılmaktadır. Ayrıca gövdesi ve dallarından elde edilen kerestesi mobilya sanayisi için oldukça değerlidir. Ceviz içi; $\% 65$ - 70 oranında doymamış yağ asitleri ve $\% 14-16$ oranında protein içermektedir. Ayrıca vitamin ve mineraller bakımından da zengindir. $\mathrm{Bu}$ besin unsurları bakımından zengin olması insan beslenmesi ve sağlığı yönünden önemini artırmaktadır (Şen 2011; Akça 2012).

Dünyadaki toplam ceviz üretimi, 2016 y1lı verilerine göre 3.80 milyon ton civarındadır. Çin, yaklaşık olarak 1.80 milyon ton üretim miktarıyla ilk sırada yer almaktadır. Çin, ABD ve İran'dan sonra dördüncü sırada yer alan Türkiye'nin toplam ceviz üretimi 195000 ton olup, ceviz ihtiyacının bir kısmını ithalat yoluyla temin etmektedir. Ceviz üretiminin tüketimi karşılama oranı 2000 yılında \%93.90 düzeyindeyken, 2017 y1lında \%76.70'e gerilemiş̧ir (Güvenç ve Kazankaya 2019).

Türkiye'de 2019 yılı verilerine göre, yaklaşık olarak 21.30 milyon adet ceviz ağacı bulunmaktadır. Bu miktarın neredeyse yarısını meyve vermeyen ağaçlar (MVMA) oluşturmaktadır. MVMA sayıs1 2004 - 2019 yılları arasında \%354.72 artmış, meyve veren ağaç (MVA) başına verim ise \%33.33 azalmıștır. Tarım ve Orman Bakanlığı tarafindan 2012 - 2016 yılları arasında yürütülen Ceviz Eylem Planı kapsamında farklı iklim koşullarına adaptasyon denemeleri yapılmadan, milyonlarca ceviz ağacının ülke geneline dağıtılması MVMA sayısının artmasina ve $30-35 \mathrm{~kg} \mathrm{MVA}^{-1}$ düzeyinde olan verimin $20-25$ $\mathrm{kg} \mathrm{MVA}^{-1}$ düzeyine gerilemesine neden olmuştur (TÜİK 2019).

MVMA sayısındaki bu artışta, mühendislik bilgisinden yoksun sulama yöntemleri kullanımının da etkili olduğu aşikârdır. Türkiye'deki ceviz bahçelerinin \%11'inde sulama sistemi bulunduğu, \%37'sinde bulunmadiğ 1 ve $\% 52$ 'sinde ise bahçenin bir kısmında bulunduğu, ayrıca ceviz bahçelerinin \%91'inin sulandığı sulama yöntemi olarak \%89 oranında salma sulama, \%11 oranında ise damla sulama kullanıldığ bildirilmektedir (Pezikoğlu ve ark. 2012).

Ceviz bahçelerinin sulanmasında bitki su tüketimin çok fazla dikkate alınmadığı salma sulama yönteminin kullanılması, bitki gelişiminde büyük bir öneme sahip olan demir mineralinin topraktan süzülen su ile beraber taşınarak, etkili kök bölgesi altında tutulmasına neden olabilmektedir. Ceviz ağacı kökleri tarafından alınamayan demir mineralinin eksikliği genç ağaçlarda sürgün kurumasına, yetișkin ağaçlarda ise meyve tutma oranının azalmasina neden olmaktadır (Horuz ve ark. 2016). Bununla birlikte sulama programlarında, yetişkin ceviz ağaçlarının su tüketiminin dikkate alınması aynı bahçede bulunan genç ağaçlara ihtiyaçlarından fazla su verilerek köklerinin çürümesine ve dolayısıyla ağaçların kaybedilmesine neden olabilmektedir (Fulton 2013).

Ceviz ağaçlarının mevsimlik su tüketimlerinin iklim koşullarına, ağacın yaşı ve çeşidine bağlı olarak 750 - $1500 \mathrm{~mm}$ arasında değiştiği, yetişkin ceviz ağaçlarında günlük ortalama su tüketiminin çiçeklenme aşamasında $2.90 \mathrm{~mm}$, meyve oluşumu aşamasında $3.97 \mathrm{~mm}$, kabuk oluşumu aşamasında $5.55 \mathrm{~mm}$ ve olgunluk aşamasında ise $3.39 \mathrm{~mm}$ düzeyinde olduğunu belirtilmektedir (Hu ve ark. 2010; Akça 2012; Akın 2016). Ayrıca, ceviz sulamasının kuraklığın yüksek olduğu yıllarda erken ilkbahar ile geç sonbahar arasında, normal yıllarda ise Haziran - Ekim döneminde yapılması gerektiği, sürgün gelişimi ve meyve büyümesinin gerçekleştiği Haziran, Temmuz ve Ağustos aylarında su tüketiminin maksimum düzeylere ulaştı̆̆ 1 bildirilmektedir (Şen 2011).

Ceviz ağaçlarının sulanması ile ilgili olarak yapılan araştırmaların çoğu yetişkin ağaçların su tüketimi, sulama suyu miktarı ve meyve verimi arasındaki ilişkileri belirlemeye yöneliktir (Cohen ve ark. 1997; Fulton ve ark. 2003; Fulton ve Buchner 2014; Akın 2016; Göçmen 2017; Jarvis-Shean ve ark. 2018). Öte yandan mevcut ceviz bahçelerindeki üretimin devamlılığının sağlanabilmesi için genç ceviz ağaçlarının yetiştirilmesine ihtiyaç duyulmaktadır. Bu ihtiyaç, $1-6$ yaş aralığındaki genç ceviz ağaçlarının su tüketiminin bilinmesi zorunlu hale getirmektedir. Bununla birlikte, Türkiye gibi kurak - yarı kurak iklim kuşağında yer alan ülkelerde yağış miktarı kararlı bitki yetiştiriciliği için yetersiz kalmaktadır. Düzensiz yağış altında bitkinin kuraklıktan zarar görmemesi için sulama yapılması zorunlu hale gelmektedir (Hillel 1982). Yetersiz su kaynaklarının etkili bir sekilde kullanımını sağlayarak su tasarrufunu artırabilmek için, bitki su tüketimine (ET) duyarlı sulama programları hazırlanarak suyun bitkiye ne zaman ve hangi miktarda verileceğinin belirlenmesi gerekmektedir. ET; bitki, toprak ve iklim özelliklerine dayalı olarak geliştirilen çeşitli ampirik yöntemler kullanılarak tahmin edilebilmektedir. Fakat bu yöntemlerin güvenilirlikleri, yöreden yöreye hatta aynı yörede yetiştirilen çeşitli bitkiler için farkl1lıklar gösterebilmektedir. Bununla birlikte yöre ve arazi koşullarına uygun olarak oluşturulan ve ișletilen lizimetreler ile gerçeğe en yakın ET miktarları elde edilebilmektedir (Doorenbos ve Pruitt 1977).

$\mathrm{Bu}$ çalışmada, Programlanabilir Lojik Kontrolör cihazı (PLC) tabanlı otomasyon sistemi tarafindan yönetilen bir tartılı lizimetre sistemi kullanılarak, iki yaşındaki Maraş 18 çeşidi genç ceviz ağacının Kahramanmaraş koşullarındaki günlük su tüketimi miktarlarının belirlenmesi amaçlanmıştır. Bununla birlikte, genç ceviz ağacının günlük su tüketimi miktarlarına bağlı olarak, Maraş 18 çeşidi yetişkin ceviz ağaçlarının günlük su tüketimi miktarlarının tahmin edilmesi hedeflenmiştir.

\section{Materyal ve Yöntem}

$\mathrm{Bu}$ çalışma, Kahramanmaraş Sütçü İmam Üniversitesi Ziraat Fakültesi Uygulama Bahçelerinde oluşturulan deneme alanında, 2018 yılının Haziran - Ekim dönemi boyunca yürütülmüștür. Deneme alanının rakımı 508 metre olup, $37^{\circ} 35^{\prime}$ 36" kuzey enlemi ve $36^{\circ} 49^{\prime} 20^{\prime \prime}$ doğu boylamı arasında bulunmaktadır. Çalışmanın yürütüldüğü Kahramanmaraş ili yazları sıcak ve kurak, kıșları 1lık ve yağışlı geçen Akdeniz iklim kuşağında yer almaktadır. Günlük ortalama hava sıcaklığı $16.90^{\circ} \mathrm{C}$, nem oran1 $\% 58.34$, ortalama güneşlenme süresi 6.77 saat gün ${ }^{-1}$ ve yıllık toplam yağış miktarı $725.40 \mathrm{~mm}$ düzeyindedir. Sulama mevsimi genellikle kurak geçmektedir (DMİ 2019).

Maraş 18 ceviz çeşidi, Kahramanmaraş orijinli olup, seleksiyon yoluyla 1slah edilmiştir. Meyve ağırlığı $14.84-15.50$ $\mathrm{g}$, iç ağırlığı $7.91-8.50 \mathrm{~g}$, verimi $50-65 \mathrm{~kg} \mathrm{MVA}^{-1}$ ve iç oranı \%52.96-56.21 arasında değişmektedir. Kahramanmaraş koşullarına en iyi adapte olan ceviz çeșididir (Kaşka ve Sütyemez 2001).

İki yaşındaki genç ceviz ağacının su tüketimini belirlemek amaciyla Şekil 1'de verilen tartılı lizimetre sistemi (TLS) kullanılmıştır. TLS; lizimetre tankı, kantar, tahliye tank1, 


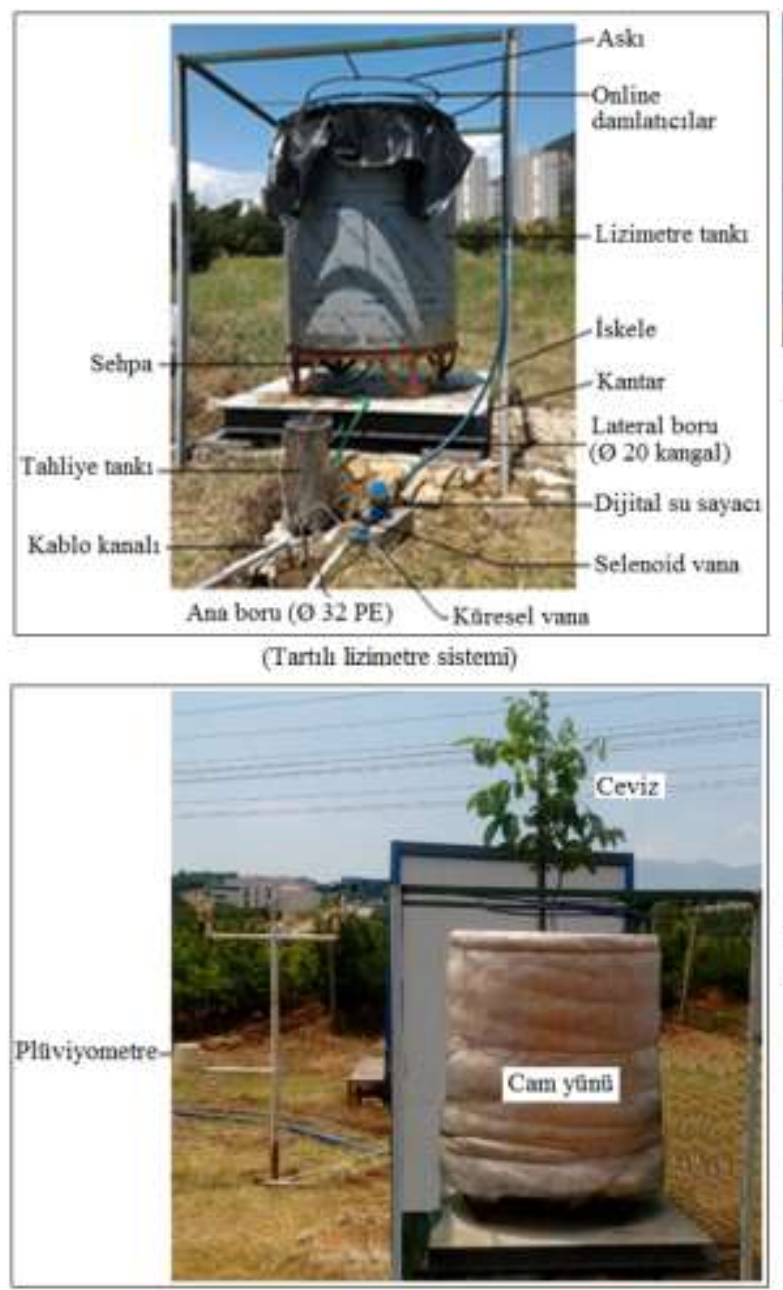

(Tartlli lizimetre sistemi)
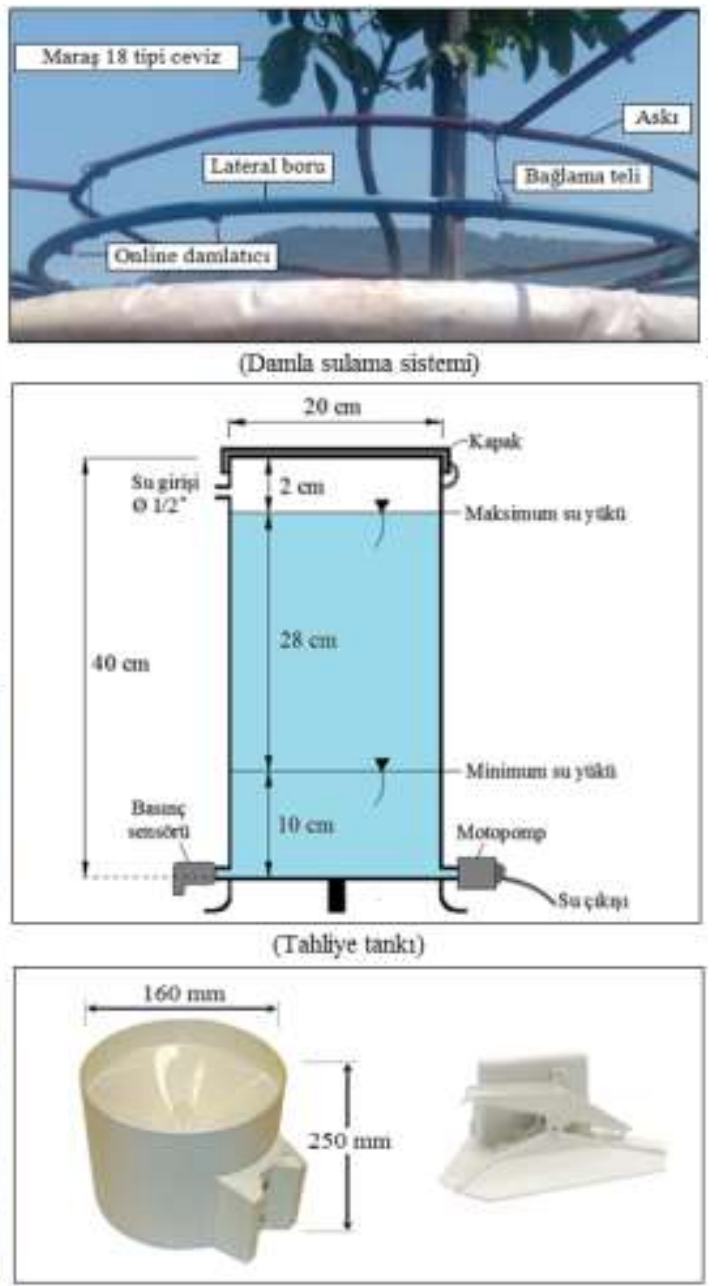

(Pliviyometre)

Şekil 1. Tartılı lizimetre sistemi.

Figure 1. Weighting lysimeter system.

plüviyometre ve damla sulama sisteminden oluşmaktadır. Lizimetre tankı $3 \mathrm{~mm}$ kalınlığındaki paslanmaz çelik sac kullanılarak $113 \mathrm{~cm}$ çapında ve $150 \mathrm{~cm}$ derinliğinde olacak şekilde imal edilmiştir. Lizimetre, toprak dışında tesis edildiğinden dolayı yüzeyi, cam yünü ile kaplanarak hava akımı ve güneş enerjisinin etkisi azaltılmıştır.

Lizimetre tankı ağırlığındaki günlük değişimi belirleyebilmek için, $1.5 * 1.5 \mathrm{~m}$ yüzey boyutlarında, $\pm 200 \mathrm{~g}$ hassasiyetle ölçüm yapabilen, 5 ton kapasiteli, 4 adet yük algılayıcısına (load cell) ve dönüştürücü karta sahip olan RS 232 çıkışlı bir elektronik kantar kullanılmıştır. Kantar bir su düzeci aracıllğı ile tesviye edildikten sonra, üzerine bir dairesel sehpa yerleştirilmiş ve onunda üzerine lizimetre tank1 konumlandırılmıştır.

Lizimetre tankından drenajla süzülen su miktarını ölçmek amacıyla, paslanmaz çelik sacdan $20 \mathrm{~cm}$ çap ve $40 \mathrm{~cm}$ yüksekliğe sahip olacak şekilde imal edilen bir tahliye tankı kullanılmıştır (Şekil 1). Lizimetre tankı tabanına $\varnothing$ 1/2" çıkış koyularak, drene olan suyun aynı çaptaki bir boru ile tahliye tankına iletilmesi sağlanmıştır. Tahliye tankında toplanan su miktarı tank tabanına yerleştirilen bir basınç sensörü vasıtasıyla ölçülmüştür. $\mathrm{Bu}$ basınç sensörü 0 - $50 \mathrm{mBar}$ arasında $\% 0.2$ hassasiyetle ölçüm yapabilmektedir. Yağışı ölçmek için ağız çap1 160 mm, yüzey alanı $20096 \mathrm{~mm}^{2}$ ve kova hacmi $4448 \mathrm{~mm}^{3}$ olan bir devrilen kovalı plüviyometre kullanılmıştır (Şekil 1).

Genç ceviz ağacının sulanmasında damla sulama yöntemi kullanılmıştır. Sulama sistemi; ana boru (Ø $32 \mathrm{PE})$, küresel vana, selenoid vana, dijital su sayac1, lateral boru (Ø 20 kangal) ve lateral boru üzerine $25 \mathrm{~cm}$ ara mesafe ile dairesel formda yerleştirilen $2 \quad 1 \mathrm{~h}^{-1}$ debili 8 adet online damlatıcıdan oluşmaktadır. Su sayacından sonraki bölüm bir iskele vasıtasıyla ceviz bitkisine ulaştırılmıştır (Şekil 1).

Lizimetre tankına yağış ve sulama ile giren suyun drenajını kolaylaştırmak amaciyla, tankın en alt kısmına $15 \mathrm{~cm}$ yüksekliğinde çakıl serilmiştir. Çakılın üzerine $0.5 \mathrm{~cm}$ gözenekli elek filtre yerleştirilmiştir. Eleğin üzerine $120 \mathrm{~cm}$ yüksekliğinde toprak doldurularak, 15.08.2018 tarihinde iki yaşındaki Maraş 18 çeşidi ceviz fidanı dikilmiştir. Tanka doldurulan toprağ 1 temin etmek amaciyla, sistemin kurulduğu alana yakın bir yerde, $1 \mathrm{~m}^{2}$ yüzey alanı altında $120 \mathrm{~cm}$ derinliğindeki toprak profili $10 \mathrm{~cm}$ yüksekliğinde tabakalar halinde kazılarak etiketli torbalara doldurulmuștur. Alınan bu topraklar aynı katman sırasına göre, sıkıştırılarak lizimetre tankına doldurulmuştur. 
Lizimetre tankına doldurulan toprağın fiziksel ve kimyasal özelliklerini belirlemek amaciyla toprak profilinin $0-30 \mathrm{~cm}$, $30-60 \mathrm{~cm}$ ve $60-90 \mathrm{~cm}$ kesitli katmanlarından bozulmuş ve bozulmamış toprak örnekleri alınarak, laboratuvar ortamında analizleri yapılmıştır (Yıldırım 2004). Bozulmuş toprak örnekleri ile yapılan analizlerden elde edilen fiziksel özellikler Çizelge 1'de verilmiştir. Toprağın hacim ağırlığı $1.36-1.50$ $\mathrm{gr} \mathrm{cm}^{-3}$ arasında olup kuru ağırlığın yüzdesi cinsinden tarla kapasitesi (TK) \%35.04-41.19 ve solma noktas1 (SN) \%20.43 - 24.17 arasında değişmektedir. Derinlik cinsinden TK, $388.52 \mathrm{~mm}$ ve SN, $210.05 \mathrm{~mm}$ olarak belirlenmiştir. Toprak profili, yüzeyden $60 \mathrm{~cm}$ derinliğe kadar killi tın (CL), geriye kalan $30 \mathrm{~cm}$ derinlikte ise kil bünyeye sahiptir (C). Bozulmamış toprak örnekleri ile yapılan analizlerden elde edilen kimyasal özellikler Çizelge 2'de verilmiştir. Topraktaki tuzların toplam miktarının bir ölçümü olarak elektriksel iletkenlik (EC) $0.018-0.022 \mathrm{dS} \mathrm{m}^{-1}$, asitlik durumunun bir ifadesi olarak da $\mathrm{pH}$ $7.61-7.80$ arasında değişmektedir. Organik madde ve kalsit $\left(\mathrm{CaCO}_{3}\right)$ oranları ile kalsiyum $\left(\mathrm{Ca}^{++}\right)$, magnezyum $\left(\mathrm{Mg}^{++}\right)$, sodyum $\left(\mathrm{Na}^{+}\right)$, potasyum $\left(\mathrm{K}^{+}\right)$katyonları ve bikarbonat $\left(\mathrm{HCO}^{-}\right.$ $\left.{ }^{3}\right)$, sülfür $\left(\mathrm{SO}_{4}^{-2}\right)$, klorür $\left(\mathrm{CL}^{-}\right)$anyonlarının miktarları da yine Çizelge 2'de verilmiştir.

Cevizin sulanmasında üniversite yerleşkesi şebeke suyu kullanılmıştır. 0.01 sodyum adsorbsiyon oranı (SAR) ile az sodyumlu sular sınıfina, $410 \mu \mathrm{S} \mathrm{m}^{-1} \mathrm{EC}$ değeri ile de tuzluluk ve sodyum açısından orta tuzlu su sınıfına giren sulama suyunun, damla sulama ile kullanıldığında herhangi bir yıkama işlemi gerektirmediği ve ceviz gibi tuza karşı hassas bitkilerde rahatlıkla kullanılabileceği görülmektedir (Wilcox 1955).

TLS, PLC tabanlı bir otomasyon sistemi tarafindan kontrol edilmiştir. $\mathrm{Bu}$ amaçla öncelikle bir pano hazırlanmıştır. Sonra kantar, plüviyometre ve tahliye tankı basınç sensörü çıkışları PLC'ye giriş olarak bağlanmıştır. Sulama sistemini kontrol eden selenoid vananın girişi ise PLC cihazının çıkışına bağlanmıştır. Daha sonra CODESYS programlama dilinde "Lizimetre", "Sulama", "Yağış", "Drenaj" ve "SD kart veri yazdırma" programları hazırlanarak PLC cihazına yüklenmiştir.

Ölçme işlemleri bir gün süreli döngüler halinde gerçekleştirilmiştir. Bir günlük süre, bir önceki gün saat 10.00 ile bir sonraki gün saat 10.00 arasındaki 24 saatlik süre olarak dikkate alınmıştır. "Lizimetre" programı ilk olarak kantardan bir günlük sürenin başındaki lizimetre ağırlığını $\left(\mathrm{W}_{1}\right)$ okumuştur. Daha sonra bir günlük süre boyunca yağış $(\mathrm{P})$ ve sulama (I) ile lizimetre tankına giren su miktarlarını ve drenaj yoluyla çıkan su miktarını $\left(D_{p}\right)$ belirleyerek, bir günlük sürenin sonundaki lizimetre ağırlığını $\left(\mathrm{W}_{2}\right)$ okumuştur. Bu değişkenleri bir boyutlu su dengesi eşitliğinde (Eşitlik 1) yerine yazarak milimetre cinsinden cevizin günlük su tüketimini (ET) belirlemiştir (Young ve ark. 1996). Bir sulama döngüsü, iki sulama arasındaki dönem olarak tanımlanmıştır. Lizimetre programı bir sulama döngüsü boyunca günlük ET miktarlarını yığışımlı

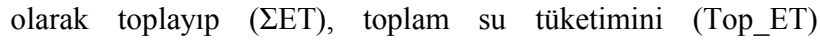
belirlemiştir (Eşitlik 2). Cevizin mevsimlik su tüketiminin $\left(\mathrm{ET}_{\mathrm{m}}\right)$ belirlenmesinde ise Eşitlik 3 kullanılmıştır.

$$
\mathrm{ET}=\mathrm{W}_{1}+\mathrm{P}+\mathrm{I}-\mathrm{D}_{\mathrm{p}}-\mathrm{W}_{2}
$$

Top_ET $=\Sigma$ ET

$$
\mathrm{ET}_{\mathrm{m}}=\Sigma \mathrm{Top} \_\mathrm{ET}
$$

Sulama zamanı, Top_ET miktarının $20 \mathrm{~mm}$ 'ye eşit veya daha büyük olduğu gün olarak dikkate alınmıştır (Top_ET $\geq 20$ $\mathrm{mm})$. İki yaşındaki genç cevizin günlük ortalama su tüketimi $2.50 \mathrm{~mm}$, sulama aralığı ise 8 gün kabul edilmiş ve Top_ET miktarı 2.50*8=20 mm olarak belirlenmiştir (Fulton 2013; Jarvis-Shean ve ark. 2018). Bu değer, sulamayı başlatan tetikleyici olarak dikkate alınmıştır. Cevizin yüksek sıcaklıklarda su stresi yaşamaması için, Top_ET miktarının $\% 120$ 'si alınmış ve bu miktar sulama suyu (I) olarak lizimetre tankı toprak yüzeyi alanına (A) uygulanmışır (Eşitlik 4). "Sulama" programı vanayı açarak sulamayı başlatmış, dijital su sayacından geçirilen su miktarı I miktarına eşit olduğunda vanayı kapatarak sulamayı bitirmiştir.

$$
\mathrm{I}=1.20 * \text { Top_ET } * \mathrm{~A}
$$

Lizimetre tankına giren günlük yağış miktarının (P) belirlenmesinde Eşitlik 5 kullanılmıştır. "Yağış" ölçümü programı plüviyometrenin yağışla dolup boşalan kova sayısını (KS) kova hacmi $\left(4448 \mathrm{~mm}^{3}\right)$ ile çarpmış ve plüviyometre yüzey alanına $\left(20096 \mathrm{~mm}^{2}\right)$ bölerek milimetre cinsinden günlük P miktarını belirlemiştir.

$$
\mathrm{P}=\mathrm{KS} * 4448 * 20096^{-1}
$$

Lizimetre tankından drenaj yoluyla süzülerek tahliye tankında toplanan günlük su miktarı $\left(D_{\mathrm{p}}\right)$, tank tabanına yerleştirilen basınç sensörü ile ölçülmüştür. Basınç sensörünün 0 - $50 \mathrm{mBar}$ aralığında ölçtüğü su yükü değerleri PLC cihazı tarafından $0-500 \mathrm{~mm}$ aralığındaki su yüksekliği değerlerine

\begin{tabular}{|c|c|c|c|c|c|c|c|}
\hline \multirow{2}{*}{$\begin{array}{l}\text { Katman derinliği } \\
(\mathrm{cm})\end{array}$} & \multicolumn{3}{|c|}{ Tane dağılımı (\%) } & \multirow{2}{*}{ Bünye sınıfi } & \multicolumn{2}{|c|}{ Toprak nemi (\%) } & \multirow{2}{*}{$\begin{array}{l}\text { Hacim ağırlı̆̆ } 1 \\
\left(\mathrm{~g} \mathrm{~cm}^{-3}\right)\end{array}$} \\
\hline & Kum & Silt & Kil & & TK & SN & \\
\hline $0-30$ & 49.50 & 20.32 & 30.18 & CL & 35.04 & 22.39 & 1.38 \\
\hline $30-60$ & 36.28 & 23.91 & 39.80 & CL & 35.99 & 24.17 & 1.36 \\
\hline $60-90$ & 31.81 & 23.97 & 44.22 & C & 41.19 & 20.43 & 1.50 \\
\hline
\end{tabular}
(SY) dönüştürülmüştür. SY değerleri, tahliye tank1 yüzey

Çizelge 1. Deneme alanı toprağının bazı fiziksel özellikleri.

Table 1. Some physical properties of soil in research field.

\begin{tabular}{|c|c|c|c|c|c|c|c|c|c|c|}
\hline \multirow{2}{*}{$\begin{array}{c}\text { Katman } \\
\text { derinliği }(\mathrm{cm})\end{array}$} & \multirow{2}{*}{$\begin{array}{c}\mathrm{EC} \\
\left(\mathrm{dS} \mathrm{m}^{-1}\right)\end{array}$} & \multirow{2}{*}{$\mathrm{pH}$} & \multirow{2}{*}{$\begin{array}{c}\mathrm{CaCO}_{3} \\
(\%)\end{array}$} & \multirow{2}{*}{$\begin{array}{c}\text { Organik madde } \\
(\%)\end{array}$} & \multicolumn{3}{|c|}{ Katyonlar $\left(\right.$ meg l $\left.^{-1}\right)$} & \multicolumn{3}{|c|}{ Anyonlar $\left(\right.$ meg l $\left.^{-1}\right)$} \\
\hline & & & & & $\mathrm{Ca}^{++}+\mathrm{Mg}^{++}$ & $\mathrm{Na}^{+}$ & $\overline{\mathrm{K}^{+}}$ & $\mathrm{HCO}^{-3}$ & $\mathrm{SO}_{4}^{-2}$ & $\mathrm{CL}$ \\
\hline $0-30$ & 0.022 & 7.61 & 9.29 & 0.88 & 2.5 & 0.16 & 0.04 & 1.6 & 0.1 & 1.0 \\
\hline $30-60$ & 0.018 & 7.76 & 7.96 & 1.76 & 3.5 & 0.51 & 0.05 & 2.1 & 0.5 & 1.5 \\
\hline $60-90$ & 0.019 & 7.80 & 9.29 & 2.67 & 2.9 & 0.27 & 0.03 & 1.7 & 0.4 & 1.1 \\
\hline
\end{tabular}

Çizelge 2. Deneme alanı toprağının bazı kimyasal özellikleri.

Table 2. Some chemical properties of soil in research field. 
alanının $\left(0.0314 \mathrm{~m}^{2}\right)$ lizimetre tankı yüzey alanına $\left(1 \mathrm{~m}^{2}\right)$ oranı $\left(0.0314 * 1^{-1}\right)$ ile çarpılarak lizimetre tankından gerçekleşen günlük $\mathrm{D}_{\mathrm{p}}$ miktarları belirlenmiştir (Eşitlik 6). Belirtilen bu işlemler "Drenaj" ölçümü programı tarafından yapılmıştır. "SD kart veri yazdırma" programı günlük ET, I, Top_ET, $P$ ve $D_{p}$ miktarlarını bir günlük sürenin sonunda saat 10.00 'da PLC cihazı üzerindeki SD karta yazdırmıştır.

$$
\mathrm{D}_{\mathrm{p}}=0.0314 * \mathrm{SY}
$$

Fulton (2013), ABD California koşullarında gerçekleştirdiği bir çalışmada 1 - 3 yaş aralığındaki Chandler çeşidi genç ceviz ağaçlarının aynı bahçede bulunan 6 yaş ve üzeri yetişkin ceviz ağaçlarının günlük su tüketiminin $\% 30-40$ '1 oranında su tükettiklerini belirlemiştir. Bu oran ortalama $\% 35$ olarak dikkate alınmıştır. İki yaşındaki Maraş 18 çeşidi genç ceviz ağacı için elde edilen günlük ortalama su tüketimi miktarları (ET genç$_{\text {) }} 0.35$ değerine bölünerek (Eşitlik 7), Maraş 18 çeşidi yetişkin ceviz ağaçlarının günlük ortalama su tüketimi miktarları (ET yetişkin) tahmin edilmiştir.

$$
\mathrm{ET}_{\text {yetiskin }}=\mathrm{ET}_{\text {genç }} *(0.35)^{-1}
$$

\section{Bulgular ve Tartışma}

Maraş 18 çeşidi genç ceviz ağacının bitki su tüketiminin belirlenmesi işlemine lizimetre tankı toprak nemi düzeyi tarla kapasitesindeyken başlanılmıştır. Lizimetre tank1 ağırlığı denemeye başlanılan 15.06.2018 tarihinde $2237.40 \mathrm{~kg}$, denemenin bitirildiği 15.10 .2018 tarihinde ise $2222.40 \mathrm{~kg}$ olarak tartılmıştır. Her bir sulama döngüsünün başında ve sonunda okunan lizimetre ağırlıkları ile her bir döngü boyunca gerçekleşen bitki su tüketimi, yağış, drenaj ve cevize verilen sulama suyu miktarları Çizelge 3'de verilmiştir. Deneme süresi boyunca toplam 12 defa sulama yapılmıştır. Sulama aralığ iklim koşullarına bağlı olarak 6 - 16 gün arasında değişmiştir.

Genç ceviz ağacının mevsimlik toplam su tüketimi $261 \mathrm{~mm}$ olarak belirlenmiştir. Deneme süresi boyunca cevize toplam 293 mm sulama suyu verilmiştir. Lizimetreye yağış ile toplam 19 $\mathrm{mm}$ su girişi olmuştur. Lizimetre tankından drenajla süzülerek tahliye tankında toplanan su miktarı ise $66 \mathrm{~mm}$ olarak ölçülmüştür. Ceviz her bir sulama döngüsünde ortalama $20 \mathrm{~mm}$ su tüketmiştir. Cevize her bir sulama döngüsünde $24-25 \mathrm{~mm}$ arasında değişen miktarlarda sulama suyu verilmiştir. Su tüketimi, sulama yapılan günlerde diğer günlere oranla daha yüksek miktarlarda gerçekleşmiştir. Sulamada damla sulama yönteminin kullanılması nedeniyle sadece toprak yüzeyi 1slatılmaktadır. $\mathrm{Bu}$ nedenle sulama yapılan günlerde toprak yüzeyinden gerçekleșen buharlaşma her zaman fazla olmuş ve su tüketimi maksimum düzeye ulaşmıştır. $\mathrm{Su}$ tüketimi, sulamadan sonraki günlerde azalma eğilimi göstermiştir. Yağış

Çizelge 3. Yağış, drenaj, sulama ve su tüketimi miktarları.

\begin{tabular}{|c|c|c|c|c|c|c|c|}
\hline Tarih & $\begin{array}{c}\text { Sulama aralığı } \\
\text { (Gün) }\end{array}$ & $\begin{array}{c}\text { İlk lizimetre ağırlığı } \\
(\mathrm{kg})\end{array}$ & $\begin{array}{l}\text { Yağış } \\
(\mathrm{mm})\end{array}$ & $\begin{array}{c}\text { Drenaj } \\
(\mathrm{mm})\end{array}$ & $\begin{array}{c}\text { Sulama } \\
(\mathrm{mm})\end{array}$ & $\begin{array}{l}\text { Su tüketimi } \\
(\mathrm{mm})\end{array}$ & $\begin{array}{c}\text { Son lizimetre } \\
\text { ağırlı̆ı̆ }(\mathrm{kg})\end{array}$ \\
\hline \multirow[t]{2}{*}{15 Haziran } & & 2237.40 & & Tarla kapa & nde başla & & \\
\hline & 11 & & & & & 21 & \\
\hline \multirow[t]{2}{*}{26 Haziran } & & 2216.40 & & & & & 2216.40 \\
\hline & 8 (1.Sulama) & & 9 & 8 & 25 & 20 & \\
\hline \multirow[t]{2}{*}{3 Temmuz } & & 2222.40 & & & & & 2222.40 \\
\hline & 6 (2.Sulama) & & 5 & 7 & 24 & 21 & \\
\hline \multirow[t]{2}{*}{9 Temmuz } & & 2223.40 & & & & & 2223.40 \\
\hline & 8 (3.Sulama) & & 0 & 6 & 25 & 21 & \\
\hline \multirow[t]{2}{*}{17 Temmuz } & & 2221.40 & & & & & 2221.40 \\
\hline & 7 (4.Sulama) & & 0 & 4 & 25 & 20 & \\
\hline \multirow[t]{2}{*}{24 Temmuz } & & 2222.40 & & & & & 2222.40 \\
\hline & 8 (5.Sulama) & & 0 & 5 & 24 & 20 & \\
\hline \multirow[t]{2}{*}{1 Ağustos } & & 2221.40 & & & & & 2221.40 \\
\hline & 7 (6. Sulama) & & 0 & 4 & 24 & 20 & \\
\hline \multirow[t]{2}{*}{8 Ağustos } & & 2221.40 & & & & & 2221.40 \\
\hline & 13 (7. Sulama) & & 0 & 6 & 24 & 20 & \\
\hline \multirow[t]{2}{*}{21 Ağustos } & & 2219.40 & & & & & 2219.40 \\
\hline & 13 (8.Sulama) & & 0 & 5 & 24 & 21 & \\
\hline \multirow[t]{2}{*}{2 Eylül } & & 2217.40 & & & & & 2217.40 \\
\hline & 9 (9.Sulama) & & 0 & 6 & 25 & 21 & \\
\hline \multirow[t]{2}{*}{11 Eylül } & & 2215.40 & & & & & 2215.40 \\
\hline & 7 (10.Sulama) & & 0 & 5 & 25 & 20 & \\
\hline \multirow[t]{2}{*}{18 Eylül } & & 2215.40 & & & & & 2215.40 \\
\hline & 16 (11.Sulama) & & 3 & 4 & 24 & 20 & \\
\hline \multirow[t]{2}{*}{4 Ekim } & & 2218.40 & & & & & 2218.40 \\
\hline & 10 (12.Sulama) & & 2 & 6 & 24 & 16 & \\
\hline 14 Ekim & & & & & & & 2222.40 \\
\hline & & Toplam & 19 & 66 & 293 & 261 & \\
\hline
\end{tabular}

Table 3. The amount of precipitation, drainage, irrigation and water consumption. 
miktarının 5.00 - $9.00 \mathrm{~mm}$ ile en yüksek değerlerine ulaştığı 26 Haziran - 9 Temmuz tarihleri arasındaki dönemde gerçekleşen drenaj (7.00 - $8.00 \mathrm{~mm})$ diğer dönemlere göre daha yüksek olmuştur.

İki yaşındaki Maraş 18 çeşidi genç ceviz ağacının 15 günlük dönemler için günlük ortalama su tüketimi miktarları belirlenerek Çizelge 4'de verilmiştir. Bu su tüketimi miktarları, Jarvis-Shean ve ark. (2018) tarafindan Amerika Birleşik Devletleri California koşullarında iki yaşındaki Chandler çeşidi genç ceviz ağaçları için belirlenen günlük su tüketimi miktarları ile karşılaştırılmıştır (Çizelge 4).

Maraş 18 çeşidi genç ceviz ağacı en yüksek su tüketimini (3.20 mm gün-1 ${ }^{-1}$ hava sıcaklığının maksimum düzeylere ulaştığ 1 $\left(29.20^{\circ} \mathrm{C}\right)$ Temmuz ayının ikinci yarısında, en düşük su tüketimini $\left(1.22 \mathrm{~mm} \mathrm{gün}{ }^{-1}\right)$ ise hava sıcaklığının minimum düzeylere düştüğü $\left(23.00^{\circ} \mathrm{C}\right)$ Ekim ayının ilk yarısında gerçekleştirmiştir. Benzer şekilde Chandler çeşidi ceviz ağacı da en yüksek (3.34 mm gün-1) ve en düşük $\left(1.19 \mathrm{~mm}\right.$ gün $\left.^{-1}\right)$ su tüketimlerini yine aynı dönemlerde gerçekleştirmiştir. Her iki genç ceviz ağacı için belirlenen su tüketimi miktarları arasında ceviz çeşidi, sulama yöntemi, arazi ve iklim koşullarının farklılığından kaynaklandığı düşünülen sapmalar olmasına rağmen, genel olarak uyumlu oldukları görülmektedir. Su tüketimi miktarları arasındaki ortalama sapma miktarı \%14 olarak belirlenmiştir. Bu sonuç, aynı yaş grubundaki her iki ceviz çeşidi için belirlenen su tüketimi miktarlarının \%86 oranında uyumlu olduğunu göstermektedir. Bununla birlikte Maraş 18 ve Chandler çeşidi ceviz ağaçlarının mevsimlik su tüketimleri sirasiyla $261 \mathrm{~mm}$ ve $289.56 \mathrm{~mm}$ olarak belirlenmiştir. Mevsimlik su tüketimi miktarlarının da uyumlu olduğu görülmektedir.

Lizimetre koşullarında iki yaşındaki Maraş 18 çeşidi genç ceviz ağacı için elde edilen günlük ortalama su tüketimi miktarları 0.35 değerine bölünerek (Eşitlik 7), aynı çeşit yetişkin ceviz ağaçlarının günlük ortalama su tüketimi miktarları tahmin edilmiş ve Çizelge 5'de verilmiştir. Haziran - Ekim dönemi boyunca Maraş 18 çeşidi yetişkin ceviz ağaçları için 3.49 - $9.14 \mathrm{~mm}$ arasında değişen günlük ortalama su tüketimi miktarları elde edilmiştir. TAGEM (2016) tarafindan hazırlanan "Türkiye'de Sulanan Bitkilerin $\mathrm{Su}$ Tüketim Rehberinde", Kahramanmaraş koşullarında yetiştirilen yetişkin ceviz ağaçları için 2.45 - $7.95 \mathrm{~mm}$ arasında değişen günlük ortalama su tüketimi miktarları verilmiştir (Çizelge 5). $\mathrm{Bu}$ rehberde yetişkin ceviz ağaçları için verilen su tüketimi miktarları ile bu çalışma kapsamında Maraş 18 çeşidi yetişkin ceviz ağaçları için elde edilen su tüketimi miktarlarının \%80 oranında uyumlu oldukları belirlenmiştir.

Akın (2016), Tekirdağ koşullarında yürüttüğü iki yıl tekerrürlü çalışma kapsamında Chandler çeşidi yetişkin ceviz ağaçlarının günlük ortalama su tüketimi miktarlarının birinci y1lda $2.60-6.60 \mathrm{~mm}$ arasında, ikinci y1lda ise $2.20-5.40 \mathrm{~mm}$ arasında değiştiğini belirlemiştir. Benzer şekilde Beede ve Fulton (2018), Amerika Birleşik Devletleri California koşullarında gerçekleştirdikleri çalışmada Chandler çeşidi yetişkin ceviz ağaçlarının günlük ortalama su tüketimi miktarlarının $2.50-8.00 \mathrm{~mm}$ arasında değiştiğini belirlemişlerdir. Her iki çalışmadan elde edilen su tüketimi miktarlarının, Maraş 18 çeşidi yetişkin ceviz ağaçları için tahmin edilen günlük su tüketimi miktarları (3.49 - $9.14 \mathrm{~mm})$ ile genel olarak uyumlu oldukları görülmektedir.
Çizelge 4. Maraş 18 ve Chandler türü genç ceviz ağaçlarının su tüketimi miktarları.

Table 4. Water consumption amounts of Maraş 18 and Chandler young walnut trees.

\begin{tabular}{ccc}
\hline \multirow{2}{*}{ Dönem } & \multicolumn{2}{c}{ Bitki su tüketimi $\left(\mathrm{mm}\right.$ gün$\left.^{-1}\right)$} \\
\cline { 2 - 3 } & Maraş 18 & Chandler \\
\hline 15-30 Haziran & 2.37 & 2.20 \\
1-15 Temmuz & 2.97 & 3.05 \\
16-31 Temmuz & 3.20 & 3.34 \\
1-15 Ağustos & 2.10 & 3.05 \\
16-31 Ağustos & 2.00 & 2.54 \\
1-15 Eylül & 2.60 & 2.03 \\
16-30 Eylül & 1.35 & 1.52 \\
1-14 Ekim & 1.22 & 1.19 \\
\hline
\end{tabular}

Çizelge 5. Maraş 18 türü yetişkin ceviz ağaçlarının su tüketimi miktarları.

Table 5. Water consumption amounts of Maraş 18 type mature walnut trees.

\begin{tabular}{ccc}
\hline \multirow{2}{*}{ Dönem } & \multicolumn{2}{c}{ Bitki su tüketimi $\left(\mathrm{mm} \mathrm{gün}^{-1}\right)$} \\
\cline { 2 - 3 } & Lizimetre & TAGEM $(2016)$ \\
\hline 15-30 Haziran & 6.77 & 7.25 \\
1-15 Temmuz & 8.49 & 7.70 \\
16-31 Temmuz & 9.14 & 7.95 \\
1-15 Ağustos & 6.00 & 7.10 \\
16-31 Ağustos & 5.71 & 7.00 \\
1-15 Eylül & 7.43 & 5.35 \\
16-30 Eylül & 3.86 & 4.55 \\
1-14 Ekim & 3.49 & 2.45 \\
\hline
\end{tabular}

\section{Sonuç}

Maraş 18 çeşidi ceviz ağacının su tüketiminin belirlenmesinin amaçlandığı bu çalışma kapsamında, öncelikle tartılı lizimetre koşullarında bir boyutlu su dengesi yöntemi uygulanarak, iki yaşındaki Maraş 18 çeşidi genç ceviz ağacının günlük su tüketimi miktarları belirlenmiştir. Daha sonra genç ceviz ağacının su tüketimi miktarlarına bağlı olarak, Maraş 18 çeşidi yetişkin ceviz ağacının günlük su tüketimi miktarları tahmin edilmiştir. Genç ceviz ağacının 2018 yılının Haziran - Ekim dönemi boyunca günlük $1.22-3.20 \mathrm{~mm}$ arasında su tükettiği ve mevsimlik su tüketiminin $261 \mathrm{~mm}$ olduğu belirlenmiştir. Maraş 18 çeşidi genç ceviz ağacı için belirlenen su tüketimi miktarlarının, aynı yaş aralığındaki Chandler çeşidi genç ceviz ağacının su tüketimi miktarları ile \%86 oranında uyumlu olduğu görülmüştür. Maraş 18 çeşidi yetişkin ceviz ağaçlarının 15 günlük dönemler için günlük su tüketimi miktarları ise Haziran ayı için $6.77 \mathrm{~mm}_{\text {gün}}{ }^{-1}$, Temmuz ay1 için 8.49 - $9.14 \mathrm{~mm}$ gün ${ }^{-1}$, Ağustos ayı için $5.71-6.00 \mathrm{~mm}$ gün $^{-1}$, Eylül ayı için $3.86-7.43 \mathrm{~mm}_{\text {gün }}{ }^{-1}$ ve Ekim ayı için 3.49 $\mathrm{mm}$ gün ${ }^{-1}$ olarak tahmin edilmiştir. $\mathrm{Bu}$ miktarlarının “Türkiye'de Sulanan Bitkilerin Su Tüketim Rehberi” ile \%80 oranında uyumlu oldukları ve yetişkin ceviz ağaçları için hazırlanacak sulama programlarında referans olarak kullanılabilecekleri sonucuna ulaşılmıştır. 


\section{Kaynaklar}

Akça Y (2012) Ceviz Yetiştiriciliği. Anıt Matbaa, Ankara.

Akın S (2016) Tekirdağ koşullarında ceviz ağaçlarının su tüketimlerinin belirlenmesi. Yüksek Lisans Tezi, Namık Kemal Üniversitesi Fen Bilimleri Enstitüsü, Tekirdağ.

Beede RH, Fulton A (2019) Irrigation Scheduling for Walnuts. University of California Farm Advisors Kings County, Hanford, California. http://cekings.ucanr.edu/files /19006.pdf. Accessed 18 February 2019.

Cohen M, Valancogne C, Dayau S, Ameglio T, Cruiziat P, Archer P (1997) Yield and physiological responses of walnut trees in semi-arid conditions application to irrigation scheduling. Acta Horticulturae 449: 273-280.

DMİ (2019) Kahramanmaraş ili 1930-2018 yılları arası aylık ortalama iklim verileri ve 2018 yılı günlük iklim verileri. Devlet Meteoroloji İşleri Genel Müdürlüğü.

Doorenbos J, Pruitt WO (1977) Crop Water Requirements. FAO Irrigation and Drainage Paper No. 24, Rome.

Fulton A, Salinas M, Montoro A, Goldhamer D (2003). Evaluation of Trunk or Scaffold Shrinkage in Walnut As an Indicator of Orchard Water Status. http://ucanr.edu/repositoryfiles/2003_135_ocr.pdf154326.pd f. Accessed 16 February 2019.

Fulton A (2013) Evaluating Water Requirements of Developing Walnut Orchards in Sacramento Valley. https:/ucanr.edu/sites/cawalnut/category/IrrSched/?reposito ry= 67403\&a=154606. Accessed 16 February 2019.

Fulton A, Buchner R (2014) Using the Pressure Chamfer for Irrigation Management in Walnut, Almond and Prune. https://ucanr.edu/datastoreFiles/391-761.pdf. Accessed 16 February 2019.

Göçmen E (2017) Tekirdağ koşullarında farklı sulama uygulamalarının ceviz ağaçlarının su kullanımı ve vejetatif gelişme unsurlarına etkisinin belirlenmesi. Doktora Tezi, Namık Kemal Üniversitesi Fen Bilimleri Enstitüsü, Tekirdağ.

Güvenç İ, Kazankaya A (2019) Türkiye'de ceviz üretimi, diş ticareti ve rekabet gücü. Yüzüncü Yıl Üniversitesi Tarım Bilimleri Dergisi 29(3): 418-424.

Hillel D (1982) Introduction to Soil Physics. Academic Press, San Diego, CA, USA.
Horuz A, Korkmaz A, Akınoğlu G, Boz E (2016) Bitkilerde demir klorozunun nedenleri ve giderilme yöntemleri. Toprak Bilimi ve Bitki Besleme Dergisi 4(1): 32-42.

Hu Q, Ma Y, He J, Zhang Q, Hong M (2010) Effect of drip irrigation and micro-sprinkler irrigation on water consumption, yields and quality of walnut. Journal of Water Resources and Water Engineering 1: 0-20.

Jarvis-Shean K, Fulton A, Doll D, Lampinen B, Hanson B, Baldwin R, Lightle D (2018) Young Orchard Handbook. http://ccfruitandnuts.ucanr.edu/files/238596.pdf. Accessed 18 February 2019.

Kaşka N, Sütyemez M (2001) Bazı yerli ve yabancı ceviz (Juglans regia L.) çeşitlerinin farklı ekolojilere uyumları üretim ve pazarlama sorunlarının belirlenmesi üzerine araştırmalar. Türkiye I. Ulusal Ceviz Sempozyumu, Tokat, s. 76.

Pezikoğlu F, Öztürk M, Tosun İ, Akça Y (2012) Seçilmiş bazı illerde kaplama ceviz bahçelerinin üretim ve pazarlama yapısı. Bahçe Dergisi 41(2): 23-35.

Şen SM (2011) Ceviz. ÜÇM Yayıncılık, Ankara.

TAGEM (2016) Türkiye'de Sulanan Bitkilerin Bitki Su Tüketimi Rehberi. T.C. Gıda, Tarım ve Hayvancılık Bakanlığı Tarımsal Araştırmalar ve Politikalar Genel Müdürlüğü (TAGEM) Yayınları, Ankara.

Toprak R, Bayrak S (1998) Aşılı Ceviz Yetiştiriciliği. Burak Ofset, Ankara.

TÜIK (2019) Türkiye'de Yetiştirilen Sert Kabuklu Meyvelerin Üretim İstatistikleri. http://www.tuik.gov.tr/PreTablo.do?alt_id=1001.Erişim 20 Şubat 2019.

Wilcox LV (1955) Classification and use of Irrigation Waters. United States Department of Agriculture, Circular No. 696, Washington D.C.

Yıldırım O (2004) Sulama. Ankara Üniversitesi Ziraat Fakültesi Yayınları, Ankara.

Young MH, Wierenga PJ, Mancino CF (1996) Large weighing lysimeters for water use and deep percolation studies. Soil Science 161: 491-501. 